\title{
The effects of international email and Skype interactions on computer-mediated communication perceptions and attitudes and intercultural competence in Taiwanese students
}

\author{
Shih-Yin Hsu \\ National Kaohsiung University of Science and Technology, Taiwan \\ Robert E. Beasley \\ Franklin College, Indiana
}

\begin{abstract}
Learners in an English as a foreign language (EFL) context seldom have the opportunity to interact with people from other cultures and experience intercultural communication in English to foster their intercultural competence (IC), whether inside or outside of the classroom. In an effort to create a brand new opportunity to boost target language interactions, this study utilised two computer-mediated communication (CMC) tools, namely email and Skype, to involve Taiwanese EFL university students in an intercultural project to discuss interesting and cultural topics with university students from the USA. Data were collected from Taiwanese students' reflective journals, a post-project questionnaire, and interviews. The study's results indicate that despite encountering numerous problems initially, Taiwanese students eventually have strong positive perceptions and attitudes toward intercultural CMC learning experiences, which can facilitate efficient online discussions with native speakers of the target language and can promote IC. Thus, endeavours to implement such expedient, innovative, and beneficial methods in foreign language courses are encouraged.
\end{abstract}

\section{Introduction}

For international transactions and communication in the contemporary multicultural and commercial world, improving students' English language competence has become an important education policy regulated by Taiwan's Ministry of Education (Wu, 2011). Yang and Chen (2014) suggest that in Taiwan, English should be taught as a means for intercultural communication so that EFL students can communicate with people from other cultures efficiently. That is, to develop students' IC, which has gained much attention from such fields as sociology, psychology, management and education (Tennekoon, 2015), should be regarded as a basic objective of EFL education (Byram, 1997; Byram \& Feng, 2004; Wach, 2015).

IC is generally not innate. Thus, it must be deliberately nurtured via education (Deardroff, 2006). Nevertheless, students in Taiwan usually lack opportunities to use English to interact with people from other cultures to develop their IC (Liaw, 2006). In the traditional grammar-translation method, language use for communication is not the target in the classroom in Taiwan. Instead, teachers use Chinese most of the time to focus on reinforcing language usage in the EFL classroom. To do well on their examinations, students just need to memorise a lot of vocabulary, phrases, and grammatical rules. Nevertheless, they have difficulties in applying the target language for real-life communication. Thus the inefficiency and inauthenticity of English language education in Taiwan does not help students improve their ability to communicate (Wu, 2010; Wu, 2011), nor, needless to say, foster their IC (Yang \& Chen, 2014).

Numerous EFL teachers today have implemented technology, especially CMC tools for students to learn English in an innovative way and prepare them for the modern digital world (Samuels, 2014; Wu, 2011). CMC, which commonly refers to any human communication via computers (Indrová, 2011), desktops, mobile phones, or other similar electronic communication technologies (Hardaker, 2010), includes both asynchronous and synchronous forms of communication. Asynchronous communication, for example email is not received or responded to simultaneously; meanwhile, synchronous communication, for example Skype, includes instant messaging, audio/video conferencing and telephone conversations (Hrastinski, 2008; Hsu \& Beasley, 2017; Stockwell, 2005). These collaborative research studies indicate that CMC tools can create authentic language use and learning environments for EFL students to communicate with native or non-native speakers. Additionally, intercultural CMC learning environments can be beneficial for fostering EFL students' IC, which a traditional EFL classroom does not (Jin, 2013, 2015; Yang \& Chen, 2014). 
This project was designed for Taiwanese students to discuss interesting and cultural topics with students from an American university to improve IC via both email and Skype. Byram's (2000) IC model and assessment criteria were used as guidelines for this study to explore Taiwanese students' IC development.

\section{Literature review}

\section{Intercultural competence (IC) in language education}

In recent years, the development of IC has been the main concern of EFL education (Espinar, Rodriguez, \& Parra 2012; Jin, 2013, 2015; Lee, 2011; Yang \& Chen, 2014; Wach, 2015). To foster IC, it is crucial to familiarise students with the target language culture (Byram \& Feng, 2004). Simultaneously, the content and topics of the students' own culture are meaningful to them because they take their role as cultural insiders and experts seriously and desire to communicate information about their own cultures accurately in international interactions (Chen \& Brown, 2012; Liaw, 2006).

Cultural knowledge alone does not lead to IC, but it should still be learned as an interpersonal and social process (Perry \& Southwell, 2011). Moreover, cultural learning in international interactions with speakers of the target language is one of the most effective channels that can lead to language proficiency, as well as IC (Yuan, 2009). Byram, Gribkova, and Starkey (2002, p. 10) acknowledge that the aims of intercultural language teaching are:

[T] g give learners intercultural competence as well as linguistic competence; to prepare them for interaction with people of other cultures; to enable them to understand and accept people from other cultures as individuals with other distinctive perspectives, values and behaviors; and to help them to see that such interaction is an enriching experience.

Although there is no conclusive agreement on a precise definition of IC, there are common and similar connotations related to IC in the literature (Moeller \& Nugent, 2014; Tennekoon, 2015). For instance, IC contains such concepts as cultural knowledge, curiosity and interest in other cultures, openness to cultural differences, intercultural sensitivity, and ability to communicate effectively with people from other cultures (Wach, 2015). According to Deardroff (2006, p. 247), IC is the "ability to communicate effectively and appropriately in intercultural situations based on one's intercultural knowledge, skills, and attitudes.” Fantini and Tirmizi (2006) also point out that IC includes four aspects (i.e., knowledge, skill, attitude, and awareness). Furthermore, IC comprises the ability to negotiate meanings across languages and cultures and prepare for living in a multicultural world (Ho, 2009). All in all, Byram (2000) offers the most comprehensive and concrete model of IC, which includes five components of IC (pp. 2-3):

1. Attitudes: curiosity and openness, readiness to suspend disbeliefs about other cultures and belief about one's own.

2. Knowledge: of social groups and their products and practices in one's own and in one's interlocutor's country, and of the general processes of societal and individual interaction.

3. Skills of interpreting and relating: ability to interpret a document or event from another culture, to explain it and relate it to documents from one's own.

4. Skills of discovery and interaction: ability to acquire new knowledge of a culture and cultural practices and the ability to operate knowledge, attitudes and skills under the constraints of realtime communication and interaction.

5. Critical cultural awareness: an ability to evaluate critically and on the basis of explicit criteria, perspectives, practices and products in one’s own and other cultures and countries.

According to Byram (2009), this model illustrates the vital traits of IC and the sorts of knowledge, skills, attitudes, and perspectives that intercultural speakers' abilities need for successful intercultural communication. Byram (2000) also offers assessment criteria for intercultural experience which includes: (a) interest in other people's way of life, (b) ability to change perspective, (c) ability to cope with living in a different culture, (d) knowledge about another country and culture, and (e) knowledge about the intercultural communication process. 
Byram's (2000) IC model and assessment criteria for intercultural experience, which provide clear and practical objectives for planning instruction and assessment activities for developing learners' IC, have been extensively accepted by many EFL teachers and researchers as guidelines for classroom practices (Jin, 2013, 2015; Liaw, 2006; Ottoson, 2013; Yang \& Chen, 2014). Thus, this study is also based on Byram's IC model and assessment criteria as frameworks for examining the enhancement of learners' intercultural learning.

\section{CMC for maximising intercultural interactions}

Educators must have innovative ways of building interesting learning environments for students in the twenty-first century if they wish to improve learning and prepare students for a multicultural world (Samuels, 2014). EFL teachers in the modern world have resorted to CMC tools to overcome distance, construct social environments, and maximise opportunities to engage students in intercultural learning so that they can discuss their knowledge, ideas, and views with speakers of the target language, and gain insight into the values and meanings of the foreign culture. Thus, CMC tools can be instrumental in facilitating the shift in focus from formal traditional classrooms to long-distance informal and intercultural collaboration and social interactions for IC development (Barrs, 2012; DelliCarpini, 2012; Li, 2015; Stantchev, Colomo-Palacios, Soto-Acousta, \& Misra, 2014; Zatarain-Cabada, Alor-Hernandez, BarronEstrada, Colomo-Palacios, \& Lin, 2016).

Nevertheless, Hsu, and Beasley (2017) found that Taiwanese EFL students experience numerous challenges in an intercultural CMC project with American students via email and Skype, especially in the initial stages. Besides overcoming deficient language skills, they have to deal with the problem of time zone differences between Taiwan and the USA, and sometimes they have to go through such technical problems as sound quality, microphones, and webcam when conducting conversations via Skype. Jin $(2013,2015)$ also affirms that not all previous intercultural CMC studies have displayed success in developing learners' IC because some learners fail to overcome misunderstandings, stereotypes, and negative attitudes about their partners' culture. Since intercultural learning is a cooperative endeavour, it is important for the teacher to guide students to build meaningful relationships with target language speakers (Moeller \&Nugent, 2014) and discover new values and beliefs to deconstruct stereotypes and prejudices (Nugent \& Catalano, 2015). Moreover, successful intercultural CMC learning depends on the teacher's particular understanding of their learners' needs to carefully create suitable activities (Blake, 2008; Yanguas, 2010). Intercultural learning is generally challenging and difficult for most of EFL participants, peculiarly during the early stages. Therefore, EFL teachers must frequently give them support in their intercultural learning processes (Chen \& Brown, 2012; Coburn, 2010).

Studies (e.g., Lim, 2017; Oztok, Zingaro, Brett, \& Hewitt, 2013) indicate that both synchronous and asynchronous communication tools have their respective advantages and limitations in online learning. In modern e-learning, it is important to know that synchronous and asynchronous communication tools should be combined to complement each other. Thus, the potential benefits of blended synchronous and asynchronous communication tools may help participants create a social scaffolding and environment, increase motivation and engagement and further develop effective learning through collaboration (Lim, 2017; Oztok, et al., 2013). To date, no studies have investigated the effects of combining synchronous and asynchronous communication tools on IC development. The current project was designed for an English for business course, which focused on developing such skills as business correspondence and telephone conversation. Accordingly, both synchronous (Skype) and asynchronous communication (email) tools were selected to provide EFL university students in Taiwan with opportunities to maximise intercultural interactions with American university students to help them develop IC.

\section{Methodology}

\section{Research questions}

The research questions, which guide this study, are as follows:

1. What are Taiwanese students' perceptions and attitudes toward intercultural CMC learning experiences?

2. To what extent do Taiwanese students develop their IC in intercultural CMC learning experiences? 


\section{Participants}

A total of 39 students taking the elective English for Business course participated in the intercultural CMC project at a university of technology in southern Taiwan. The 39 participants, who were Chinese users and generally had intermediate-level English, consisted of 11 seniors, 26 juniors, and 2 sophomores from different departments. However, after some time, 5 students dropped out of the project; a total of 34 students completed the project.

Another group students ( $n=32,25$ women and 7 men) from a Midwestern American university who were invited to participate in the intercultural CMC project were native speakers of English. Students from both countries were assigned to groups based on similar interests or hobbies. The numbers of students enlisted in the two groups were not even. Hence, some American students had more than one Taiwanese student as their cohort.

\section{Context and procedures}

This project was conducted during the fall semester of 2012 by utilising action research. Through action research, the teacher/researcher could analyse what happened and what she had to do to adjust and refine her instructional strategies to motivate her students' active participation (Koshy, 2010). In Taiwan, there are 18 weeks in each semester. Students met 2 hours per week in the course. Participation in the out-ofclass activities was compulsory for the Taiwanese students. They were required to use English to write at least one email to their American counterparts every week. Alternatively, they could chat with them via Skype.

After completing their intercultural interactions, the students had to write in their reflective journals to describe and reflect on their actual intercultural learning experiences and then upload them to the teacher/researcher's website. According to this requirement, each student had to accomplish at least 15 reflective journal entries. At the end of the project, a total of 522 reflective journal entries were collected to prove students' active participation. This research focused only on understanding Taiwanese students' development of IC. American students' intercultural experiences and reflections were not investigated.

\section{Topics and learning activities for the intercultural Skype project}

During the first week of the course, the students were given an orientation where they learned such things as netiquette, email formatting, the significance of IC, the use of email and Skype, and the purpose of the project. At the same time, the students discussed and chose their favourite topics, which mirrored their cultures, interests, and everyday lives. They were also asked to do research on these topics for online discussions outside of the classroom and bring their intercultural learning experiences into the classroom every week to share. Moreover, they were required to learn, for instance, how to initiate conversation, think in English rather than translate, use key words and guessing, and catch main ideas when using English in an authentic online communication. During the second week, the students introduced themselves to their American cohorts via email and discussed with them the specific times they could interact via Skype. Beginning with the third week, the students discussed their favorite topics with their American counterparts. The weekly topics for the project are presented in Table 1.

Table 1

Overview of topics

\begin{tabular}{clcl}
\hline Week & Topic & Week & Topic \\
\hline 1 & Orientation & 2 & Self-Introductions \\
3 & Life at University & 4 & Mid-autumn Festival \\
5 & Night Markets & 6 & Ghost Month in Taiwan \\
7 & Halloween & 8 & Who does the Housework? \\
9 & Dragon Boat Festival & 10 & Lantern Festival
\end{tabular}




\begin{tabular}{llll}
11 & Size Discrimination & 12 & Thanksgiving \\
13 & Living Together before Marriage & 14 & Is It OK for Women to Propose to Men? \\
15 & Who Takes Care of Elderly Parents? & 16 & Christmas \\
17 & Chinese New Year & 18 & Post-project Questionnaire and Interviews \\
\hline
\end{tabular}

\section{Data collection and analysis}

At the end of the project, a post-project questionnaire, which included two parts was distributed to investigate: (a) the EFL students' perceptions of the project, and (b) the EFL students' IC development. All of the responses on the questionnaire were collected using a 5-point Likert scale. Face-to-face, in-depth, semi-structured interviews were conducted as well. Each interview lasted approximately 30 to 40 minutes. All interviews were audio-recorded, transcribed, and translated from Chinese to English for a qualitative data analysis. The first part of the questionnaire and interviews were carefully examined and coded. The findings collected helped answer the first research question: "What are Taiwanese students' perceptions and attitudes toward intercultural CMC learning experiences?”

Based on a modified version of Byram's (2000) assessment criteria, students' reflective journals were also closely examined. The six categories of IC used for the project included: (1) interest in knowing other people's perspective and way of life, (2) interest in introducing one's own perspective and culture to others, (3) ability to change perspective, (4) knowledge about one's own country and culture, (5) knowledge about another country and culture, and (6) knowledge about the intercultural communication process.

The data collected from the second part of the questionnaire and the interviews were analysed to seek further evidence and information in order to supplement and confirm students' IC, which was demonstrated in their reflective journals. All data were content analysed and coded to help answer the second research question: "To what extent do Taiwanese students develop their IC in intercultural CMC learning experiences?”

To sum up, the post-project questionnaire, interviews, and reflective journals were collected for qualitative data analysis. These data sources were triangulated to reduce bias and increase the reliability and validity of the research (Merriam, 2002). A summary of the data sources and analysis of the research questions is listed in Table 2.

Table 2

Summary of data collection and analysis

\begin{tabular}{cll}
\hline Research question & Data collection & $\begin{array}{l}\text { Methods } \\
\text { of analysis }\end{array}$ \\
\hline $\begin{array}{c}\text { 1. What are Taiwanese students' perceptions } \\
\text { and attitudes toward intercultural CMC } \\
\text { learning experiences? }\end{array}$ & $\begin{array}{l}\text { The first part of the } \\
\text { questionnaire and interviews }\end{array}$ & $\begin{array}{l}\text { Descriptive } \\
\text { analysis }\end{array}$ \\
$\begin{array}{c}\text { 2. To what extent do Taiwanese students } \\
\text { develop their IC in intercultural CMC } \\
\text { learning experiences? }\end{array}$ & $\begin{array}{l}\text { Reflective journals, the second } \\
\text { part of the questionnaire and } \\
\text { interviews }\end{array}$ & $\begin{array}{l}\text { Content } \\
\text { analysis }\end{array}$ \\
\hline
\end{tabular}

\section{Results}

\section{Students' perceptions and attitudes toward intercultural CMC learning experiences}

The analysis of the first part of the post-project questionnaire (Table 3) and interviews indicates that the students began the project feeling frightened $(M=4.44)$ and encountered difficulties initially, peculiarly when using Skype $(M=4.56)$ to communicate with their American partners. All of them affirmed that they did not have any cross-cultural communicational experiences with people from other countries via CMC tools before this project $(M=5.00)$. According to their interview reports, they felt insecure and afraid of using English to communicate with people in both written and spoken forms at first. The students 
acknowledged that as a result of the new learning scenario, it was the most difficult time for them to adjust to authentic language use situations through CMC tools. In contrast to Skype conversations, email writing allowed them to have more time to think in terms of how to express themselves in English and work at their own pace. In other words, it was much more of a struggle and much more of a challenge to adapt to real verbal communication through Skype. Due to shyness and fear, the students felt very uncomfortable meeting new people and chatting with them via Skype. In addition, they feared that their language skills were not sufficient enough to respond and interact impromptu. Besides these difficulties, some of them also stated that they had negative stereotypes and prejudices about their American counterparts and their culture. For instance, they thought Americans were arrogant and had sense of superiority. Thus, they commented that the entirely new learning experience was quite challenging for them originally.

Table 3

Students' perceptions of intercultural learning experience

\begin{tabular}{|c|c|c|}
\hline Item & $M$ & $S D$ \\
\hline $\begin{array}{l}\text { I did not have intercultural communicational experiences with people from other } \\
\text { countries via CMC tools (e.g. Email, Skype, and Facebook) before this project. }\end{array}$ & 5.00 & 0.00 \\
\hline $\begin{array}{l}\text { I felt frightened initially because I did not have any cross-cultural communicational } \\
\text { experiences with people from other countries via CMC tools before this project. }\end{array}$ & 4.44 & 0.50 \\
\hline $\begin{array}{l}\text { I encountered difficulties of using Email to learn to communicate with my American } \\
\text { partner at the beginning of the project. }\end{array}$ & 4.29 & 0.52 \\
\hline I appreciated the teacher’s support and clear instruction during this project. & 4.41 & 0.50 \\
\hline $\begin{array}{l}\text { I liked the topics that reflect my interests and my culture to communicate with my } \\
\text { American partner. }\end{array}$ & 4.24 & 0.43 \\
\hline $\begin{array}{l}\text { I felt the strategy training is crucial for me to learn to develop more effective } \\
\text { learning strategies. }\end{array}$ & 4.03 & 0.30 \\
\hline $\begin{array}{l}\text { I became friends with my American partner because of the intercultural CMC } \\
\text { project. }\end{array}$ & 4.75 & 0.44 \\
\hline $\begin{array}{l}\text { I became more comfortable and confident of using CMC tools to interact with my } \\
\text { American partner after training in the project. }\end{array}$ & 4.09 & 0.28 \\
\hline I liked to use Email to improve my English writing. & 4.53 & 0.51 \\
\hline I liked to use Skype to improve my English speaking. & 4.88 & 0.33 \\
\hline This project helped me improve my English language learning. & 4.82 & 0.29 \\
\hline This project helped me improve my culture learning. & 4.91 & 0.29 \\
\hline $\begin{array}{l}\text { I would like to participate in more intercultural CMC learning projects } \\
\text { in the future. }\end{array}$ & 4.65 & 0.49 \\
\hline I enjoyed learning English through the intercultural CMC project. & 4.79 & 0.41 \\
\hline Overall, I had a strong positive opinion of the project. & 4.74 & 0.45 \\
\hline
\end{tabular}

At the end of the project, we noticed that the students' attitudes changed from negative to positive toward intercultural learning experiences and that they made the transition from non-English users to relaxed and adept users in authentic language use situations when using CMC tools. We also detected that, as the students interacted with their American counterparts, they became more familiar with them, and their negative stereotypes and prejudices toward Americans and their culture were gone. In addition, teamwork and mutual support were developed, and they felt less intimidated. They also concurred that they progressed gradually from being initially uncomfortable with the instructional approach to becoming comfortable and confident in using CMC tools to interact with their American partners $(M=4.09)$. Indeed, international friendships and collaboration played a crucial role in contributing to the students' confidence, progress, and 
growth in IC. As Ming (all names used are pseudonyms throughout this paper, and translations were made from Chinese to English) commented:

I saw many changes in myself. Initially, I felt terribly nervous because I thought that my American partner might be too unfriendly to endure my poor English. I was wrong. Actually, she was very friendly and patient. She gave me a lot of encouragement. Now I am quite confident and relaxed while writing emails and talking with her. Even if I make grammatical mistakes in writing and speaking, I do not mind. Most importantly, I really enjoy discussing with her and exchanging our cultural knowledge and views.

The following report also illustrates how international friendships play a significant role in helping students learn and grow. As Ting commented:

I was very lucky to have a very nice American friend as my partner. Sara was always very patient. If I did not understand the words she said, she typed them out. She often said that my English is very good. I really appreciate her encouragement. Eventually it was easy for me to understand her through emails and via Skype. She often told me that I could contact and ask her at any time if I had any English language or American culture questions. I'll continue to contact her through Skype. I think it is the best way to learn English and learn about each other's culture.

As they developed their social and affective dimensions, the students really enjoyed using Skype. As Hsosing stated:

It was fun and nice talking with my American friend, Jane, by using Skype. Through video calls, we could see each other. It was as if we were talking to each other face to face. Both of us enjoyed learning from each other this way. Although there were some language, cultural, and technical barriers, and even time differences, we both struggled to overcome these difficulties. At first, I used a lot of body language. Now I can handle a conversation confidently. We tried to contact with each other on weekends regularly. Jane loved to learn Chinese and Chinese culture as well. I taught her how to use chopsticks and how to count numbers in Chinese.

Yi-ting also reported:

Near the end of the project, my American friend said that my English was getting better. She was impressed. She said that English is difficult to learn. My English was very good for one of my first times using it in speaking. She really enjoyed talking with me and learning about me and what I like to do and my culture. She hopes that we can be good friends forever. She showed me a picture of her studying for her final exams.

The teacher also played an essential role in the students' development in the intercultural project. Our findings also indicated that they appreciated the teacher's support and clear instruction during the project ( $M=4.41)$. According to their comments, the teacher's careful guidance, pedagogical applications, and intervention were important and helped them overcome numerous difficulties. In addition, it was necessary to choose the topics that reflect their interests and their culture to communicate with their partners $(M=$ 4.24). Thus, they became more eager and confident to actively participate in intercultural learning activities. As they reported, to gain more cultural knowledge, learn more useful words and phrases, and make precise statements about cultures in English, they were encouraged to actively research cultural topics by reading books, magazines, and online resources. The results of this research also indicated that the students gradually developed learner autonomy and improved their learning habits. Furthermore, they responded that strategy training is crucial for developing more effective learning strategies $(M=4.03)$. According to their reports, strategy training helped them learn to communicate with their international partners more efficiently.

There was also a noticeable transformation in the students' affective progress. They eventually shifted from fear to enjoyment in not only written but also in spoken communications. The high mean scores of the postproject questionnaire showed that they like to use email $(M=4.53)$ to improve their writing and Skype $(M$ 
$=4.88$ ) to improve their speaking. They enjoyed learning English through the intercultural CMC project $(M=4.79)$. The project helped them not only improve their English language learning $(M=4.82)$ but also cultural learning $(M=4.91)$. Furthermore, they would like to participate in more intercultural CMC learning projects in the future $(M=4.65)$. Moreover, they commented enthusiastically on the value of engaging in intercultural CMC learning. For example, Su-yi said, "I appreciated this intercultural learning opportunity. Accordingly, I had a chance to gain authentic American culture as well as authentic use of English.”

Overall, the students had a strong positive opinion of the project $(M=4.74)$. Many of them believed that oral communication skills and email writing would be two crucial skills in their future jobs. They hope that they can develop these two essential skills before they graduate from the university. The above statements indicate that the intercultural CMC learning technologies of email and Skype and language use were interesting, essential, and significant enough to satisfy students' learning needs. They appreciated having the opportunity for social interactions across cultures in an authentic communicative context.

\section{Assessment of Taiwanese students' IC in intercultural CMC learning experiences}

A close analysis of 522 student reflective journal entries revealed examples of the six types of IC: (1) interest in knowing other people's perspective and way of life, (2) interest in introducing one's own perspective and culture to others, (3) ability to change perspective, (4) knowledge about one's own country and culture, (5) knowledge about another country and culture and (6) knowledge about the intercultural communication process. The high mean scores of the second part of the post-project questionnaire (Table 4) and interviews also confirmed these findings. The quotations are the original students' writing.

Table 4

Students' Self-Assessment of Developing IC

\begin{tabular}{lcc}
\hline Category & $M$ & $S D$ \\
\hline I developed interest in knowing American’s way of life. & 4.30 & .66 \\
I developed interest in introducing my own perspective and culture to others. & 4.45 & .51 \\
I developed ability to change perspective. & 3.40 & .50 \\
I developed knowledge about my own country and culture. & 4.31 & .47 \\
I developed knowledge about Americans and their culture. & 4.15 & .37 \\
I developed knowledge about the intercultural communication process. & 3.92 & .52 \\
\hline
\end{tabular}

Category 1. Interest in knowing other people's way of life

The students' reflective journals frequently revealed the category, interest in knowing other people's way of life. For instance, they enthusiastically raised many questions to express their interests and curiosities in their American counterparts' various life experiences, in particular, their college lives and the ways they celebrate Halloween, Thanksgiving, and Christmas. As shown in Hsia-Cheng's reflective journal:

I like to know about American students' way of life. Today I asked many questions about my American friend's life in college. She answered all the questions clearly and in detail. As I learned, she has had a very busy schedule. In order to obtain scholarships and grants, she has to study hard. She has a part-time job on campus. She participates in several clubs and organizations as well. I think she is a studious student and enjoys a lot at her college.

The questionnaire and interviews corroborated the findings that the students were interested in knowing the American's way of life $(M=4.30)$ and that they would like to know more about their cultural differences. In summary, the students' strong interest in other cultures and their strong desire to know more about cultural differences provide evidence of their positive attitudes, an indispensable element of IC. The students gradually developed confidence in intercultural communication and gained authentic knowledge of American culture from first-hand information. 
Category 2. Interest in introducing one's own perspective and culture to others

The category, interest in introducing their own perspective and culture to others, was also a frequent category in the students' reflective journals. Students energetically used their personal experiences and knowledge to introduce their own perspectives and their own cultures. As Hai-an illustrated in her reflective journal:

Today I introduced the mid-autumn festival to my American friend through Skype. She liked my story of the mid-autumn festival. Through Skype video, I showed her moon cakes and pomelos. She likes to learn Chinese. She often wanted me to teach her many things in Chinese. Yes, of course, I love to teach her Chinese. I feel very proud that I can teach her the Chinese language and introduce her to our special customs and interesting festivals in Taiwan.

From the students' post-project questionnaire and interviews, we learned that they were interested in introducing their own perspective and culture to others $(M=4.45)$ and that they felt proud that they have the ability to do so. In short, CMC tools of email and Skype provided effective platforms for students to socially interact with people from other cultures. Their interest in introducing their own perspectives and culture to others helped their American friends learn something unique. Thus, in the intercultural CMC project, they not only learned American ways of life, cultural values, and beliefs, but they also learned more about their own culture. The students gradually fostered intercultural knowledge, the one indispensable element of IC.

Category 3. Ability to change perspective

The category, ability to change perspective, was the one category with the least number of student reflective journal entries. Although the students enthusiastically introduced their own cultures and shared their experiences and knowledge of their own cultural issues, there was not much room left for changes in perspective. However, when discussing such topics as: "Is it ok for women to propose to men?" and "living together before marriage”, in which different cultural values and cultural differences might exist between American and Taiwanese students, the Taiwanese students somewhat demonstrated the ability to change perspective. As Wan-ching wrote in her reflective journal:

It was very interesting to discuss the topic “Is It OK for Women to Propose to Men?" In Taiwan, most people think that women should not propose marriage. My American friend said that women and men are equal; women should be allowed to propose freely; everyone has the right to propose and decline a proposal as well. I completely agreed with her. I know it is not our culture, but times have changed. I may propose to my boyfriend some years later if we really love each other. Men and women should be equal! Am I right? Yes, definitely!

This was the category with the lowest mean score in the questionnaire $(M=3.40)$. They might not believe that they have changed their own perspectives in such a short time. However, many of them commented during their interviews that they were willing to change perspectives if they found that other cultural values and beliefs are better and more suitable for the times. This finding may well suggest that the project has helped them become more open-minded, respectful, and curious and less judgmental about others' cultures.

In brief, this intercultural project seemed to promote the students' ability to think and evaluate critically and become more aware of perspectives, which differed from theirs. It even seemed to develop their ability to change perspective to some degree. Therefore, in intercultural learning processes, they fostered critical cultural awareness, one of the vital elements of IC.

Category 4. Knowledge about one's own country and culture

The category, knowledge about one's own country and culture, was also a recurrent theme in the students' reflective journals. They knew how to engage in conversation with their American cohorts by using some important facts about, and by expressing their own experiences of, living in their own country and culture. As Chiao-ping wrote in his reflective journal:

My American friend was very happy to hear when I was talking about "Chinese New Year.” She asked me many questions. I was happy that I was able to tell her all I know. I told her that during Chinese New Near, my parents give us money with red envelopes. She asked me why they give money with red envelopes. I explained that Chinese people prefer to give or receive money instead of gifts; red color means "good luck" and "happiness.” Now I am a 
student. I can still get red-envelop money. After I graduate from college, I will get a job and make money. I will give my parents red-envelope money in return. She said that she liked the Chinese culture. I am very proud that I have a lot of knowledge about my culture to share with her.

This category also received a high mean score on the questionnaire $(M=4.31)$. Many students commented that, as they became more familiar with their American partners, they felt more confident and enthusiastic about their ability to thoroughly demonstrate their knowledge of their own country and culture. They used such words as "proud," “enjoyable," “motivating," and "confident” to describe their feelings because they had so much to offer and share with their American partners about their own country and culture.

To sum up, the results of this project seems to verify the fact that students know how to contribute important facts about Chinese culture purposefully in order to maintain conversations with their American cohorts. Indeed, students frequently demonstrated their own cultural knowledge and positive attitude in an effort to promote intercultural communication.

Category 5. Knowledge about another country and culture

The students' reflective journals revealed that they boosted their knowledge about the USA and American culture. Thanks to the interaction, they learned some important facts about living in the USA and knew how to maintain a conversation with their American counterparts by using their newly-acquired intercultural knowledge. As Kin-lan noted:

It was interesting to hear that Tim needed to do a lot of housework at home. He had to mow his house lawn and had to take turns with his sisters to feed chickens, geese, dogs, cats.... So, I bet his house is very huge. In Taiwan, it is hard to keep animals in our apartments. My mum does not want me to do the housework because I am a boy. I just need to study hard to get good scores and enter a good university. Compared to Tim, I am quite immature. I learned a lot from him. Before, all my knowledge about Americans and American culture was just from Hollywood movies. I thought that American children were spoiled. My assumption was wrong.

The results of this study showed that students developed knowledge about the USA and American culture $(M=4.15)$. According to their reports, they discovered that they had previously had very limited knowledge, or even wrong assumptions and negative stereotypes about Americans and their culture. Accordingly, they deeply appreciated the precious opportunity to learn and gain knowledge about American culture from firsthand sources.

In brief, the CMC tools utilised in the project offered strong and enjoyable platforms for the students to interact with American students and helped them obtain authentic knowledge of American culture, learn different ways of life and cultural values, and allow them to correct wrong assumptions or stereotypes. The CMC tools helped them develop skills of discovery and interaction, the essential element of IC.

Category 6. Knowledge about the intercultural communication process

The category, knowledge about the intercultural communication process, was also an important theme in the students' reflective journals. That is, they knew how to resolve misunderstandings when they arose from peoples' lack of awareness of cultural differences, and they discovered new information of the other culture for themselves during the intercultural communication process. As illustrated in Min-yin's reflective journal:

Jimmy was really surprised to learn that we went to school on Christmas Day in Taiwan. So I tried to explain that Christmas is a traditional and important holiday in the USA because many people are Christians there. But, very few people are Christians in Taiwan. Also, our main traditional religions are Buddhism and Taoism. So, December 25 is not a special day for most Taiwanese. He finally understood why December 25 is not a holiday in Taiwan.

The questionnaire showed that the students developed knowledge about the intercultural communication process $(M=3.92)$. Some of them commented that occasionally, when misunderstandings arose from a shortage of intercultural awareness and understanding, they had to display knowledge about the intercultural communication process. That is, they had to utilise such skills as interpreting, relating, 
comparing, and explaining what causes differences between two cultures to resolve and avoid misunderstandings.

In summary, the students demonstrated their intercultural knowledge, keen motivation and desire to improve intercultural communication. To bridge the communication gap and avoid misunderstandings, they utilised such skills as interpreting, relating, comparing, and explaining cultural differences and discovering new information, which are all crucial elements of IC.

\section{Discussion and conclusion}

The purpose of this research was to look into the pedagogical design of applying email and Skype to the development of EFL students' IC by having them discuss interesting and intercultural topics with their American partners. The findings indicate that their teacher's instructional strategies and support and their American cohorts' friendships and collaboration became important sources in helping the students avoid being overwhelmed by initial challenges and furthermore have strong positive perceptions and attitudes toward intercultural CMC learning experiences. As a result, they developed their intercultural knowledge, skills, attitudes, and critical cultural awareness, the vital elements of IC, and became successful intercultural speakers (Byram, 1997; Liaw, 2006). Simultaneously, they exhibited six types of IC: (1) interest in knowing other people's way of life, (2) interest in introducing one's own perspective and culture to others, (3) ability to change perspective, (4) knowledge about one's own country and culture, (5) knowledge about another country and culture, and (6) knowledge about the intercultural communication process. Although not yet excellent, the students' IC was one survival skill that they could draw upon to communicate effectively across cultural borders (Tennekoon, 2015). As Byram et al. (2002, p. 7) pointed out: “To be a successful intercultural speaker and mediator does not require complete and perfect competence.” In short, the goals set for the pedagogical design of the intercultural CMC activities were successfully achieved.

This study had several limitations. First, the small number of participants at the same university might have negative implications for the external validity of the results. Second, the study focused exclusively on understanding Taiwanese EFL students’ perceptions and IC enhancement in intercultural learning. It would be worthwhile to further explore American students' IC development or differences in perceptions between the two groups. Third, five students failed to complete the project, and their motivations for doing so were not investigated. Examining these motivations might yield some important insights. Fourth, the duration of this project was only slightly more than 4 months. A longer-term study may be needed to more fully understand students' learning processes when developing IC. Fifth, whether or not the Skype and email interactions are still going on is not known. This knowledge would be essential to scrutinising and discussing whether the intercultural CMC learning project would be a long-term activity for lifelong learning. As can be seen from these limitations, more research is still needed.

Despite the limitations of this research, our project has nevertheless provided some insight into utilising CMC tools for boosting EFL language learning. For example, the use of CMC tools can be an effective approach to making up for insufficient direct contact with native speakers of the target language in EFL contexts. Intercultural CMC projects can also help students be ready for the demands of an increasingly interconnected world and succeed in today's technology-rich environments in their future careers (Ho, 2009; Kinshuk, Chen, Cheng, \& Chew, 2016; Moeller \& Nugent, 2014; Voogt \& Knezek, 2016). In this study, the students built friendships, not antagonists. This finding suggests that offering opportunities for intercultural learning may help acquire an understanding of human rights and respect for others (Byram et al., 2002) and may further develop world peace and social harmony (Tennekoon, 2015; Tochon, 2014). At the same time, intercultural learning can provide deep language learning rather than surface learning (i.e., teaching to the test) (Tochon, 2014). In a nutshell, the employment of CMC tools can offer an authentic, innovative, and effective way to gain access to cross-cultural interactions to develop EFL learners' IC. This IC will certainly help them be more ready for and effective in their future jobs.

\section{Acknowledgements}

We would like to express our gratitude to the anonymous reviewers and referees for their careful reading of our manuscript and for their insightful comments/suggestions that led to significant improvements in this paper. We would also like to thank the students who participated in the project and shared their special experiences and thoughts with us. 


\section{References}

Barrs, K. (2012). Action Research: Fostering computer-mediated L2 interaction beyond the classroom. Language Learning \& Technology, 16(1), 10-25.

Blake, R. (2008). Brave new digital classroom: Technology and foreign language learning. Washington, WA: Georgetown University Press.

Byram, M. (1997). Teaching and assessing intercultural communicative competence. Clevedon: Multilingual Matters.

Byram, M. (2000). Assessing intercultural competence in language teaching. Sprogforum, 18(6), 8-13.

Byram, M. (2009). Intercultural competence in foreign languages: The intercultural speaker and the pedagogy of foreign language education. In D. K. Deardorff (Ed.), The Sage handbook of intercultural competence (pp.321-332). Los Angeles, CA: Sage.

Byram, M., \& Feng, A. (2004). Culture and language learning: teaching, research and scholarship. Language Teaching, 37(3), 149-168. Retrieved from http://dro.dur.ac.uk/1701/1/1701.pdf

Byram, M., Gribkova, B., \& Starkey, H. (2002). Developing the intercultural dimension in language teaching: A practical introduction for teachers. Strasbourg: Council of Europe. Retrieved from http://www.coe.int/t/dg4/linguistic/source/guide_dimintercult_en.pdf

Chen, J. C. C., \& Brown, K. L. (2012). The effects of authentic audience on English as a second language (ESL) writers: A task-based, computer-mediated approach. Computer Assisted Language Learning, 25(5), 435-454.

Coburn, J. (2010). Teaching oral English online - through Skype (VOIP). Acta Didactica Norge, 4(1), 128.

Davis, R. (2014). Voice and text chat: Communicating across the Internet. Retrieved from http://www.esllab.com/tips/voice-chat.htm

Deardorff, D. K. (2006). Assessing intercultural competence in study abroad students. In M. Byram, \& A. Feng, (Eds.), Living and studying abroad: Research and practice (pp.232-256). Clevedon: Multilingual Matters.

DelliCarpini, M. (2012). Action research: Building computer technology skills in TESOL teacher education. Language Learning and Technology, 16(2), 14-23.

Elola, I., \& Oskoz, A. (2008). Blogging: Fostering intercultural competence development in foreign language and study abroad contexts. Foreign Language Annals, 41(3), 454-477.

Espinar, A. M. L., Rodriguez, A. R. R., \& Parra, M. E. G. (2012). ICT for intercultural competence development. Pixel-Bit. Revista de Medios y Educacion, 40(Enero/January 2012), 115-124. Retrieved from http://www.redalyc.org/articulo.oa?id=36823229009

Fantini, A. E., \& Tirmizi, A. (2006). Exploring and assessing intercultural competence. World Learning Publications. Paper 1. Retrieved from http://digitalcollections.sit.edu/worldlearning_publications/1

Hardaker, C. (2010). Trolling in asynchronous computer-mediated communication: From user discussions to academic definitions. Journal of Politeness Research, 6(2), 215-242. Retrieved from http://clok.uclan.ac.uk/4980/

Ho, S. T. K. (2009). Addressing culture in EFL classrooms: The challenge of shifting from a traditional to an intercultural stance. Electronic Journal of Foreign Language Teaching, 6(1), 63-76.

Hrastinski, S. (2008). Asynchronous and synchronous e-learning. EDUCAUSE Quarterly, 31(4), 51-55. Retrieved from https://er.educause.edu/articles/2008/11/asynchronous-and-synchronous-elearning

Hsu, S. Y., \& Beasley, R. (2017). Using an intercultural CMC project to help technological university students in Taiwan promote five language skills. Journal of English Education, 5(2), 1-34.

Indrová, T. (2011). Spoken, written and computer-mediated communication: The language of online discussion forums (Bachelor's diploma thesis). Masaryk University, Brno, Czech Republic. Retrieved from https://is.muni.cz/th/331015/ff_b/Indrova_Tereza-Spoken_Written_and_ComputerMediated_Communication.pdf

Jin, S. (2013). The use of Facebook to promote Korean learners' intercultural competence (Doctoral dissertation). The Pennsylvania State University, PA. Retrieved from https://etda.libraries.psu.edu/files/final_submissions/8909

Jin, S. (2015). Action research: Using Facebook to promote Korean EFL learners' intercultural competence. Language Learning \& Technology, 19(3), 38-51. Retrieved from http://lit.msu.edu/issues/october2015/action2.pdf

Kinshuk, Chen, N. S., Cheng, I. L., \& Chew, S. W. (2016). Evolution is not enough: Revolutionizing current learning environments to smart learning environments. International Journal of Artificial Intelligence in Education, 26(2), 561-581. http://dx.doi/10.1007/s40593-0160108-x 
Koshy, V. (2010). Action research for improving educational practice: A step-by-step guide. London: Sage.

Lee, L. (2011). Blogging: Promoting learner autonomy and intercultural competence through study abroad. Language Learning and Technology, 15(3). 87-109. Retrieved from http://lit.msu.edu/issues/october2011/lee.pdf

Li, K. (2015). Learning styles and perceptions of student teachers of computer-supported collaborative learning strategy using wikis. Australasian Journal of Educational Technology, 31(1), 32-50.

Liaw, M. Y. (2006). E-learning and the development of intercultural competence. Language Learning \& Technology, 10(3), 49-64. Retrieved from http://lt.msu.edu/vol10num3/liaw/

Lim, F. P. (2017). An analysis of synchronous and asynchronous communication tools. Advanced Science and Technology Letters, 143(AST 2017), 230-234. Retrieved from http://dx.doi.org/10.14257/astl.2017.143.46

Merriam, S. B. (2002). Qualitative research in practice: Examples for discussion and analysis. San Francisco, CA: Jossey-Bass.

Moeller, A. K., \& Nugent, K (2014). Building intercultural competence in the language classroom. In S. Dhonau (Ed.), Unlock the gateway to communication: Central States Conference Report (pp. 1-18). Eau Claire, WI: Crown Prints. Retrieved from http://digitalcommons.unl.edu/cgi/viewcontent.cgi?article=1160\&context=teachlearnfacpub

Nugent, K., \& Catalano, T. (2015). Critical cultural awareness in the foreign language classroom. NECTFL Review, 75(January 2015), 15-30. Retrieved from http://digitalcommons.unl.edu/cgi/viewcontent.cgi?article=1193\&context=teachlearnfacpub

Ottoson, K. J. (2013). Classroom development of intercultural competence. N. Sonda, \& A. Krause (Eds.), JALT 2012 Conference Proceedings, 119-129. Tokyo: JALT. Retrieved from http://www.unifg.it/sites/default/files/allegatiparagrafo/21-012014/ottoson_classroom_development_of_intercultural_competence.pdf

Oztok, M., Zingaro, D., Brett, C., \& Hewitt, J. (2013). Exploring asynchronous and synchronous tool use in online courses. Computers and Education, 60(1), 87-94.

Perry, L. B., \& Southwell, L. (2011). Developing intercultural understanding and skills: Models and approaches. Intercultural Education, 22(6), 453-466.

Samuels, D. R. (2014). The culturally inclusive educator: Preparing for a multicultural world. New York, NY: Teachers College Press.

Stantchev, V., Colomo-Palacios, R., Soto-Acosta, P., \& Misra, S. (2014). Learning management systems and cloud file hosting services: A study on students’ acceptance. Computers in Human Behavior, 31, 612-619.

Stockwell, G. (2005). Syntactical and lexical development in NNS-NNS asynchronous CMC. The JALT CALL Journal, 1(3), 33-49.

Tennekoon, S. R. (2015). Crossing the cultural boundaries: Developing intercultural competence of prospective teachers of English. International Journal of Scientific and Research Publications, 5(4), 1-15. Retrieved from http://www.ijsrp.org/research-paper-0415/ijsrp-p4082.pdf

Tochon, F. V. (2014). Help them learn a language deeply - Francois Victor Tochon's deep approach to world languages and cultures. Madison, WI: Deep University Press.

Voogt, J., \& Knezek, G. (2016). Guest editorial: Technology enhanced quality education for all-outcomes from EDUsummIT 2015. Educational Technology \& Society, 19(3), 1-4.

Wach, A. (2015). Advanced learners' intercultural experience through computer-enhanced technology: A study of Polish and Romanian students. In L. Piasecka, M. Adams-Tukiendorf, \& P. Wilk (Eds.), New media and perennial problems in foreign language learning and teaching, (pp. 21-38). Opole: Springer.

Wu, K. H. (2010). The relationship between learners’ anxiety and learning strategy in the CLT classrooms. International Education Studies. 3(1), 174-191. Retrieved from https://files.eric.ed.gov/fulltext/EJ1066074.pdf

Wu, T. Y. (2011). Learning English in Taiwan’s elementary schools. Journal of Futures Studies, 16(2), 3546. Retrieved from http://www.jfs.tku.edu.tw/16-2/A03.pdf

Yang, S. C., \& Chen, J. J. (2014). Fostering foreign language learning through technology-enhanced intercultural project. Language Learning \& Technology, 18(1), 57-75.

Yanguas, I (2010). Oral computer-mediated interaction between L2 learners: It's about time. Language Learning \&Technology, 14(3), 72-93.

Yuan, W. (2009). Effectiveness of communication between American and Chinese employees in multinational organizations in China. Intercultural Communication Studies, 18(1), 188-04. 
Zatarain-Cabada, R., Alor-Hernández, G., Barrón-Estrada, M. L., Colomo-Palacios, R., \& Lin, H. C. K. (2016). Guest editorial. Intelligent and affective learning environments: New trends and challenges. Educational Technology \& Society, 19(2), 1-4.

Corresponding author: Shih-Yin Hsu, teesssh@gmail.com

Australasian Journal of Educational Technology (C) 2019.

Please cite as: Hsu, S.-Y., \& Beasley, R. (2019). The effects of international email and Skype interactions on computer-mediated communication perceptions and attitudes and intercultural competence in Taiwanese students. Australasian Journal of Educational Technology, 35(1), 149-162. https://doi.org/10.14742/ajet.4209 